\title{
Observation of Overlying Strata Failure Height in Fully Mechanized caving in Tongxin mine
}

\author{
Yansen Huai, Wenyong Liu, Pengshuai Fang \\ Resource\&Safety School, China University of Minging\&Technology (Beijing), Beijing 100083,China; \\ huaiyansen@126.com
}

Keywords: Fully mechanized caving mining, Overlying strata failure height, Color borehole TV observation, detailed description of drilling process, core drilling integrity rate

\begin{abstract}
The deformation and failure of overlying strata in mined out aera was produced by the traditional caving mining, and the distribution pattern of "three zones" was formed. In which the height of water flowing fractured zone is an important parameter for safe and efficient mining of "three down" coal seam. Therefore, it is very important to observe and analyze the height of "three zones" by reasonable means. Color borehole TV observation, detailed description of drilling process and core drilling integrity rate are used in the 8101 working face mining goaf Tongxin mine Datong coal mine group to observe the height distribution of "three zones". And comparised with the theoretical calculation results in fully mechanized caving mining, The results show that color borehole TV observation, detailed description of drilling process and core drilling integrity rate to test the height of "three zones" in fully mechanized top coal caving is reasonable and accurate.
\end{abstract}

\section{Introduction}

Coal mining destroyed the protolith of the rock stress field, the mining field rock stress re distribution, especially deformation failure of the roof surrounding rock in large area over the goaf, formed the distribution of "three zones", followed by caving zone, water flowing fractured zone and bending subsidence zone. The distribution height and shape of the "three zones" is an important parameter for mining design and safe mining in "three under" coal seam ${ }^{[1-2]}$. The determination of overburden failure height can be obtained by field observation, empirical formula prediction, numerical simulation calculation and so on ${ }^{[3]}$. Because of the fully mechanized top coal caving with large mining height used in 8101 working face Tongxin mine, the caving zone, water flowing fractured zone height was significantly increased, in order to prevent the surface river water poured into goaf, to ensure safety production, Drilling holes are arranged on the surface over the goaf of 8101 caving face, to measure and analysis the failure height of goaf overburden by the borehole TV imaging observation and detailed description of drilling process and core drilling integrity rate and so on. The observation results are consistent with the theoretical calculation results of overburden failure height under the condition of fully mechanized caving mining, which means that the observation and analysis method is suitable and accurate.

\section{Mine Survey and hydrogeological conditions}

Tongxin mine is the main coal mine, with an annual output of 10 million tons. The main face of 8101 lane near Kouquan River, preventive measures should be taken for the ground tenants and Kouquan river during mining.

Coal seam of 8101 working face is $3-5 \#, 0.35 \sim 4.14 \mathrm{~m}$ below $2 \#$, the structure is more complex. For a huge thick seam, layer thickness is about $11.0 \sim 23.64 \mathrm{~m}$, with an average of $14.13 \mathrm{~m}$. Inclined length is $200 \mathrm{~m}$, the strike length is $1678 \mathrm{~m}$, the use of fully mechanized top coal caving with large mining height, mining 3.9 meters high, top coal thickness is 11.4 meters, caving ratio is 1:2.9. Table 1 is the roof and bottom plate of the coal seam. 
Table 1 The roof and bottom plate of the coal seam.

\begin{tabular}{|c|c|c|c|}
\hline $\begin{array}{l}\text { Name of top } \\
\text { and bottom } \\
\text { plate }\end{array}$ & Rock name & Thickness(m) & Lithologic character \\
\hline Basic top & $\begin{array}{l}\text { Gravel bearing } \\
\text { sandstone }\end{array}$ & $2.20 \sim 8.30$ & $\begin{array}{l}\text { Component quartz, feldspar dominated, } \\
\quad \text { Gravel diameter } 1 \sim 4 \mathrm{~cm} \\
\text { Poor sorting, pore filling water, K3 } \\
\text { sandstone }\end{array}$ \\
\hline Driect top & $\begin{array}{l}\text { Sandy } \\
\text { mudstone and } \\
\text { carbonaceous } \\
\text { mudstone }\end{array}$ & $0.80 \sim 6.50$ & $\begin{array}{l}\text { Flat fracture, bedding development, } \\
\text { brittle friable }\end{array}$ \\
\hline Driect bottom & $\begin{array}{l}\text { Toner rocks } \\
\text { and Kaolinite }\end{array}$ & $0.50 \sim 4.90$ & $\begin{array}{l}\text { Brittle, fragile, conchoidal fracture, a } \\
\text { thin layer of coal dust in the folder }\end{array}$ \\
\hline
\end{tabular}

\section{Field observation and analysis}

\subsection{Equipment introduction}

Wuhan Chang-Sheng JL-IDOI(A) intelligent drilling television imaging instrument was used in Drilling test, as figure1. JL-IDOI(A) of intelligent drilling television imaging instrument consists of the host, the cable winding wire frame and optical probe, using advanced DSP image collecting and processing technology, is a highly integrated system, probe the panoramic camera, real-time automatic profile extraction, clear and vivid images, automatic accurate calibration of the range and depth, the full range of all the observation hole, the cylindrical imaging, is currently the most advanced drilling TV imaging system.

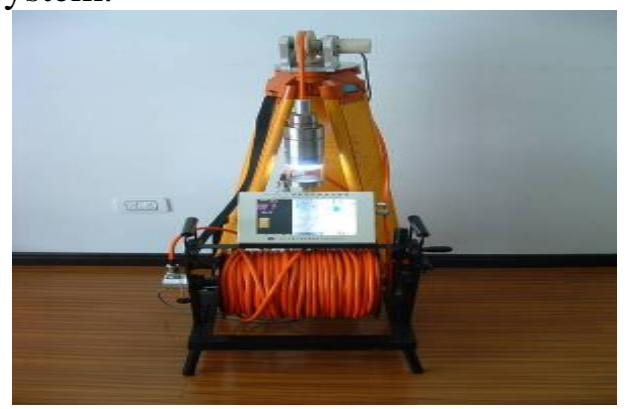

\subsection{Borehole layout and field observation method}

Fig.1 Color borehole TV system

The drilling hole is located in the vertical surface position of the 8101 working face, and the distance from the 8101 working face about $456 \mathrm{~m}$, from transport lane about $32 \mathrm{~m}$, borehole coordinate $\mathrm{X}=4432113.350, \mathrm{Y}=550271.180, \mathrm{Z}=1219.934 \mathrm{~m}$ (provided by the drill team), frame height of $0.5 \mathrm{~m}$, the drilling position corresponding to $3-5 \#$ coal seam floor elevation is about $782 \mathrm{~m}$, bored opening position away from the coal seam floor of vertical distance is $437.5 \mathrm{~m}$.

From the goaf side surface to the underground was drilled, with a total of 360 meters deep, the final hole diameter $98 \mathrm{~mm}$, opening diameter $133 \mathrm{~mm}$. From the orifice to the underground $309 \mathrm{~m}$ the casing were implanted into, the casing outer diameter is $127 \mathrm{~mm}$, an inner diameter is $113 \mathrm{~mm}$. Begin to coring from the orifice down $311 \mathrm{~m}$, until the distance surface $355 \mathrm{~m}$, a total of 13 times coring, core net long $15.3 \mathrm{~m}$ and core drilling rate sample seen Table 2, the core drill figure in Fig.2. Table 2 shows that in the number $3(315.03-317.67 \mathrm{~m})$ and number $4(317.67-320.24 \mathrm{~m})$ the core remove rate is from $90.9 \%$ down to $50.6 \%$. It shows that the distribution of this segment is changed. In the number 13 (351.31-355.52m) the core of extraction rate turns into zero, indicating that this section of the rock has been very broken.

Drilling television observation implementation steps are divided into: drilling location selection, surface drilling, installation of casing, Equipment installation commissioning start observation, image processing analysis. 
Table 2 Core drilling rate sample

\begin{tabular}{|c|c|c|c|c|}
\hline No. & Hole depth / m & Total length/m & Core length / & Core rete/\% \\
\hline 1 & $311.4-313.62$ & 2.22 & 1.7 & 76.6 \\
\hline 2 & $313.62-315.03$ & 1.41 & 1.1 & 78.0 \\
\hline 3 & 315.03-317.67 & 2.64 & 2.4 & 90.9 \\
\hline 4 & $317.67-320.24$ & 2.57 & 1.3 & 50.6 \\
\hline 5 & $320.24-324.74$ & 4.5 & 1.8 & 40.0 \\
\hline 6 & $324.74-329.35$ & 4.61 & 0.8 & 17.4 \\
\hline 7 & $329.35-333.61$ & 4.26 & 1.4 & 32.9 \\
\hline 8 & $333.61-335.42$ & 1.81 & 0.6 & 33.1 \\
\hline 9 & $335.42-340.03$ & 4.61 & 1.7 & 36.9 \\
\hline 10 & $340.03-343.90$ & 3.87 & 0.6 & 15.5 \\
\hline 11 & $343.90-346.70$ & 2.8 & 0.7 & 25.0 \\
\hline 12 & $346.70-351.31$ & 4.61 & 1.2 & 26.0 \\
\hline 13 & $351.31-355.52$ & 4.11 & 无 & 0 \\
\hline & $\frac{2 \frac{1}{2}}{2 \frac{2}{2}}$ & \multirow[t]{2}{*}{ 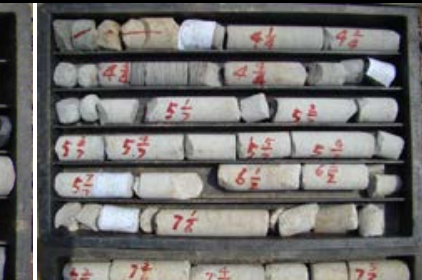 } & \multicolumn{2}{|c|}{ 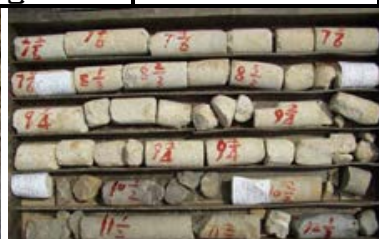 } \\
\hline & $13 \frac{6}{7}$ & & $172]\left[-12 \frac{2}{3}\right.$ & \\
\hline
\end{tabular}

Number $1 \sim 3$ core Number $4 \sim 7$ core Number $7 \sim 12$ core

Fig. 2 core drill figure

\subsection{Observation results and analysis}

\subsubsection{Analysis of the measured results of the first drill hole $\mathrm{Z1}$}

It is too large Water Leakage to continue with muddy water drilling in the position of 345m distance from the ground. After consultation, continue to drill with pure water, often lost during drilling. From $355 \mathrm{~m}$ to $360 \mathrm{~m}$, the card drill, drop drill and drilling tool vibration is serious, there is a clear suction phenomenon in the drill. From the borehole television observation image analysis, more than 340m the borehole image of rock is fragmentation, and accompanied by a larger hole gap. And from the core drilling rate sample table 1 , more than $350 \mathrm{~m}$, the core remove rate is down to $0 \%$, which indicates that the section of the rock is very broken. According to the past experience of exploration team and discussion of expert group, 360m of the hole depth is determined for the position of the upper limit of the caving zone, and height of orifice distance coal seam floor is $437.5 \mathrm{~m}$. The height of caving zone is calculated as ${ }^{[4]}$ :

$$
\mathrm{H}_{\mathrm{m}}=\mathrm{H}-\mathrm{h}-\mathrm{W}
$$

$\mathrm{H}_{\mathrm{m}}$ as caving zone height, $\mathrm{m} ; \mathrm{H}$ as orifice distance coal seam roof height, $\mathrm{m}$; h as orifice distance the caving zone height limit, $\mathrm{m}$; $\mathrm{W}$ as rock fracture belt compression values during drilling observation, $\mathrm{m}$.

$14.3 \mathrm{~m}$ is adopted in the coal seam mining in the $\mathrm{Z} 1$ borehole, $\mathrm{M}=14.3 \mathrm{~m}, \mathrm{~W}=0.2 \mathrm{M}, \mathrm{W}=2.86 \mathrm{~m}$. Then it is concluded that height of the caving zone $\mathrm{H}_{\mathrm{m}}$ is calculated as $60.34 \mathrm{~m}$.

The first observation height is from $307.1 \mathrm{~m}$ to $339.7 \mathrm{~m}$, at $339.7 \mathrm{~m}$ the camera can not be delegated, stop observation at $339.7 \mathrm{~m}$, a total observation of $32.6 \mathrm{~m}$. Seen from the image, before $321.4 \mathrm{~m}$ rock complete with tiny cracks, after cracks continuous, and appears several bit off phenomenon, and in which rock breakage is serious, empty appears several times, consistent with core drilling process, in $323.5 \mathrm{~m}$ bits off 0.5 meters, in $333.4 \mathrm{~m}$ bits off 0.4 meters, as Figure 3 shows. Table 1 indicates that the drilling curvature of this section is decreased from $90.9 \%$ to less than $50.6 \%$. It shows that the formation of the rock is changed, and the degree of fragmentation is aggravated. Therefore $321.5 \mathrm{~m}$ is determined as the the upper limit of water guide height in Z1 drilling hole. Orifice distance distance coal seam floor height is $437.5 \mathrm{~m}$.

The formula for calculating the height of water flowing fractured zone is ${ }^{[5]}$ :

$$
\mathrm{H}_{\mathrm{li}}=\mathrm{H}-\mathrm{h}+\mathrm{W}
$$

Formula: $\mathrm{H}_{\mathrm{li}}$ as the height of the water flowing fractured zone, $\mathrm{m} . \mathrm{H}$ as orifice distance roof 
height, $\mathrm{m} . \mathrm{h}$ as the distance of orifice caving zone height limit, $\mathrm{m}$; $\mathrm{W}$ as rock fracture belt compression values during drilling observation, $\mathrm{m}$. Then it is concluded that the height of the water flowing fractured zone $\mathrm{H}_{\mathrm{li}}$ is $98.84 \mathrm{~m}$.
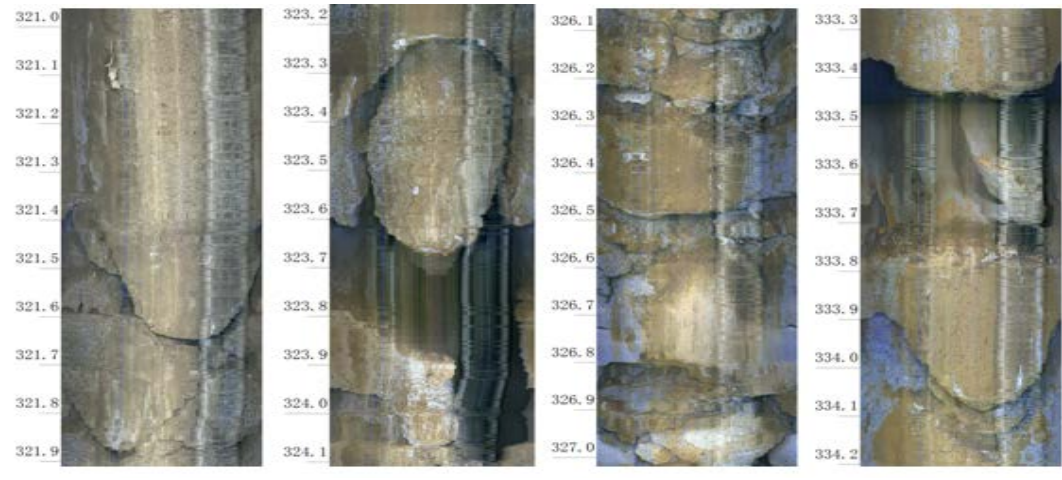

Fig3. Part of Z1borehole television observation map

\subsubsection{Analysis of the measured results of the second drill hole $\mathrm{Z2}$}

The height of caving zone is still based by the detailed description of the drilling process, core drilling integrity rate and the borehole television observation image. The height of the caving zone height is the same as that of the first observation, and the height of the caving zone is $60.34 \mathrm{~m}$.

$\mathrm{Z} 2$ borehole observation height is from $307.1 \mathrm{~m}$ to $349.9 \mathrm{~m}$ distance from the ground surface, a total observation height of $42.8 \mathrm{~m}$. From $322 \mathrm{~m}$ the rock is crushed, during the core drilling process core drill appears several bit off, off $0.5 \mathrm{~m}$ at $324.1 \mathrm{~m}$, off $0.3 \mathrm{~m}$ at $334.1 \mathrm{~m}$, and consistent with borehole television viewing image, as shown in Fig.4. It shows that the formation of the rock is changed, and the degree of fragmentation is aggravated. Therefore $322 \mathrm{~m}$ is determined as the the upper limit of water guide height in $\mathrm{Z} 2$ drilling hole. Orifice distance coal seam floor is $437.5 \mathrm{~m}$. According to the formula above, the height of water flowing fractured zone $\mathrm{H}_{\mathrm{li}}$ is $98.34 \mathrm{~m}$.
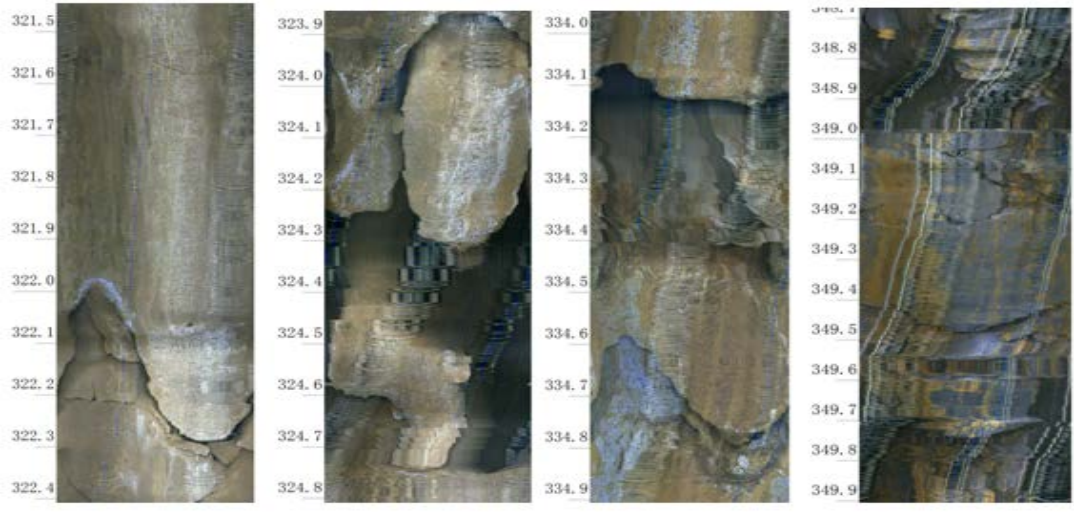

Fig4. Part of Z2 borehole television observation map

\subsection{Analysis of measured results}

Due to the caving zone can not form a complete holes. Therefore, the borehole television can not observe the rock fracture morphology in caving zone, only through a detailed record of drilling process and core drilling complete rate to judge the caving zone height. The height of caving zone is $60.34 \mathrm{~m}$, which is 4.2 times of mining thickness, and the height of water flowing fractured zone is about $98.5 \mathrm{~m}, 6.8$ times of mining thickness. It shows that the height of caving zone and water flowing fractured zone in the fully mechanized top coal caving mining are higher than that in the normal thick coal seam ${ }^{[6]}$.

\section{Comparison to the theoretical calculation of the "three zones" height in fully mechanized caving}

In the <buildings, water, railway and main roadway coal pillar left design and coal mining regulations $>$ (hereinafter referred to as $<$ Regulations $>)^{[7]}$, There are experienced formula to calculate the height of caving zone and water flowing fractured zone under the condition of fully mechanized and layered general collected of thick coal seam, but without corresponding formulas 
for thick coal seam with large mining height and fully mechanized carving, so rules can not be used in the formula to be compared. In reference ${ }^{[8]}$ caving zone, water flowing fractured zone height were measured, then regression analysised, obtained a comprehensive formula for calculating the height of the condition above, through more than 40 mines in fully mechanized caving mining, as shown in the following table 3:

Table 3 The empirical formula of height of the"two belts"

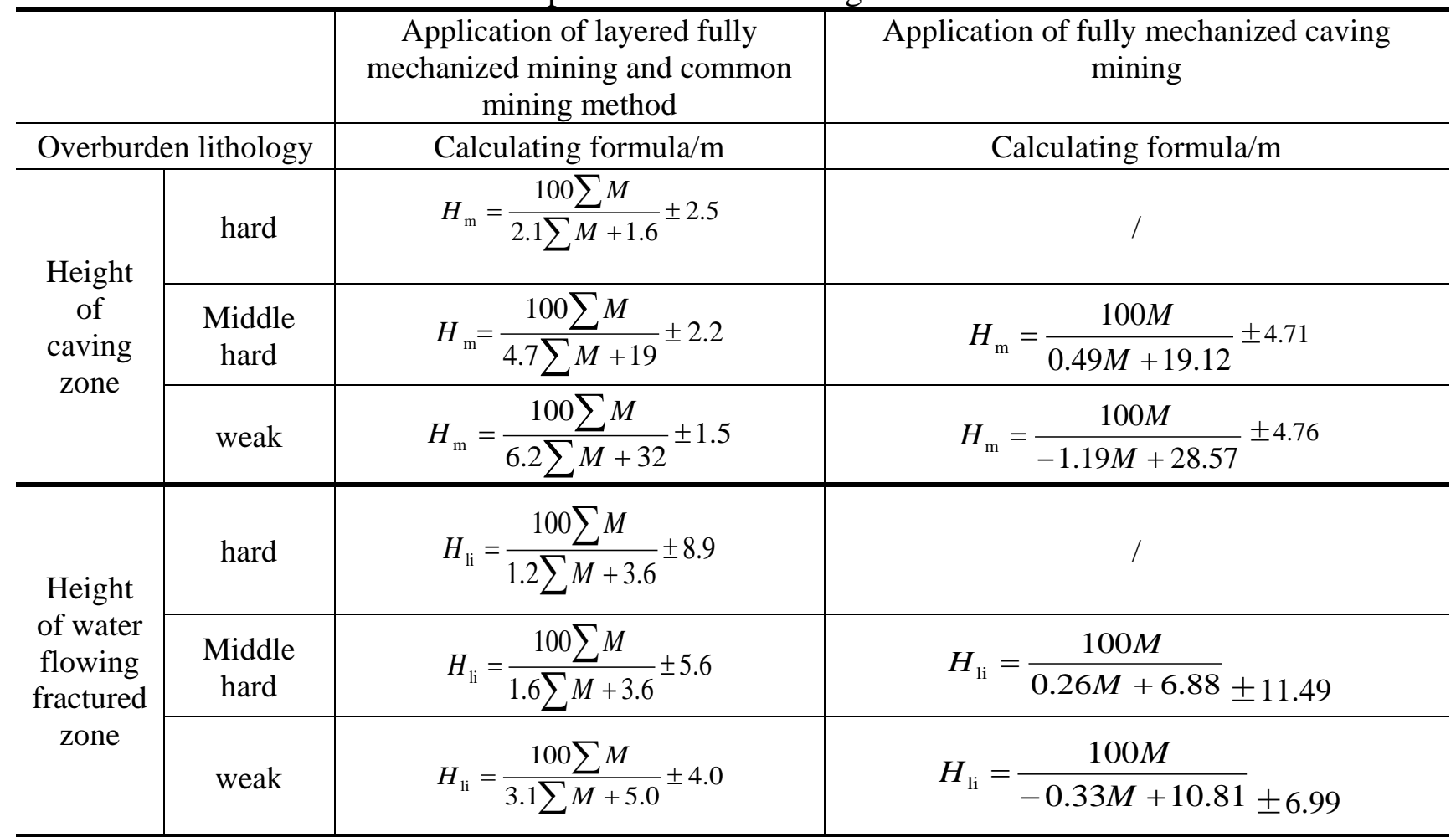

Considering of the overlying strata lithology and geological conditions, the overlying strata in gob is middle hard rock, caving zone and the water flowing fractured zone height were calculated from the above formula respectively, caving zone height as $50.1 \mathrm{~m}$ to $59.4 \mathrm{~m}$, water folwing fracture zone height as $123.4 \mathrm{~m} \sim 146.4 \mathrm{~m}$. It is concluded that the theoretical calculation results are in agreement with the field measurements. If the $<$ Regulations $>$ calculation formula is used, the height of caving zone is $14 \mathrm{~m} \sim 20 \mathrm{~m}$, and that of water flowing fractured zone is $50 \mathrm{~m} \sim 60 \mathrm{~m}$. So it can be obtained that the damage height of overlying strara is very different from fully mechanized caving mining to layered mining or tiered conventional mining in thick coal seam by the practice of field measurement and theoretical calculation results.

\section{Conclusion}

(1) Borehole TV imaging observation and detailed description of drilling process and core drilling integrity rate has strong adaptability to make a judgment of overburden failure development. It has important guiding significance for the safety, efficient mining to "three down" coal seam.

(2) The height of caving zone and water flowing fractured zone were obtained by the methods mentioned above. The height of caving zone is $60.34 \mathrm{~m}, 4.2$ times of mining thickness, and that of water flowing fractured zone is $98.5 \mathrm{~m}, 6.8$ times of mining thickness.

(3) In accordance with the<Regulations $>$, the height of caving zone and fractured zone in thick coal seam respectively is $14 \mathrm{~m} \sim 20$ and $50 \mathrm{~m} \sim 60 \mathrm{~m}$. But according to the calculation formula of fully mechanized caving in thick coal seam, the height of caving zone is from $50.1 \mathrm{~m}$ to $59.4 \mathrm{~m}$, and that of water flowing fractured zone is 123.4 to $146.4 \mathrm{~m}$. On one hand, it verified the experimental results and theoretical calculation results are in good agreement. The measured results has a certain reference value; another that thick coal seam in fully mechanized caving, overburden failure height can not be calculated in accordance with the $<$ Regulations $>$. The calculation results show relatively small. 


\section{Reference}

[1] Rules for the design of buildings, water bodies, railways and main shaft of the coal mining industry [S], Beijing: Coal Industry Press, 2000

[2] Qian Ming-gao, Shi Ping-wu. Mine pressure and rock strata control [M]. Xuzhou: China University of Mining and Technology press, 2003

[3] Beijing Mining Research Institute. The law of surface movement and overburden failure of coal mine and its application [M]. Beijing: China Coal Industry Press, 1981

[4] Chen Rong-hua, Bai Hai-bo, Feng Mei-mei. Determination of the height of water flowing fractured zone in overlying strata of fully mechanized caving face [J]. Journal of mining and safety engineering, 2006,5 (10): 42-44.

[5] Kang Yong-hua. Borehole observation method for overburden failure [J]. coal science and technology, 2002, 30 (12)

[6] Shen Bao-hong, Kong Qing-jun. Observation and Study on the law of overburden failure in the fully mechanized caving face [J]. coal field geology and exploration, 2000, 5 (10):42-44

[7] Zou Hai, Wang Guiliang, et al. Prediction method for the height of water flowing fractured zone in fully mechanized coal caving mining COAL GEOLO GY \&EXPLORATION [J]., 1998, 26 (12): 43-46

[8] Xu Yan-chun, Li Jun-cheng, Liu Shi-qi, et al. Height calculation formula and adaptability analysis for Fully mechanized top coal caving mining overburden "two zones". Coal mining technology, 20112 (16): 4-7 